\title{
Türkiye’de Kamu Katılım Bankalarının Bankacılık Sektörü Bazında Değerlendirilmesi: CAMELS Analizi İle 2015-2017 Yıllarına İlişkin Bir İnceleme*
}

\author{
Tuğba EYCEYURT BATIR**
}

\section{$\ddot{O Z E T}$}

Türkiye'de önemli bir potansiyele sahip olan katılım bankactlğ̆l sektörüne 2015 yll itibartyla sirasiyla Ziraat Bankası ve Vakıfbank gibi kamu bankalarının dahil olması büyük önem taşımaktadır. Devletin katılım bankacılı̆̆ sektörüne girmesinin sisteme olumlu etkide bulunacă̆ı tahmin edilmektedir.

Bu çalışmada temel amaç, katılım bankalarının CAMELS değerlendirme sistemi ile değerlendirilmesi ve yeni kurulan kamu katılım bankalarının faaliyete geçtiği 2015 yılından 2017 yılına kadar aktif katılım bankalarının mukayeseli olarak incelenmesidir. Analiz sonucuna göre kamu katılım bankalarının CAMELS sistemini oluşturan bazı kalemlerde sektör altında nota sahip olmasına rağmen ortalama CAMELS reytinginde sektörün üzerinde bir puana sahip olduğu görülmüş̧ür.

Anahtar Kelimeler: Katılım bankacılı̆̆ı, Kamu katılım bankaları, CAMELS değerlendirme sistemi.

JEL Siniflandirmasi: G10, G21, M40

Evaluation Of State Participation Banks On The Basis Of Banking Sector In Turkey: A Research Between The Years Of 2015 - 2017 By Using CAMELS Analysis

\section{ABSTRACT}

The entrance of state participation banks by 2015 such as Ziraat Bank and Vakifbank respectively to the participation banking sector which has an important potential in Turkey is of capital importance. It is thought that the entry of the state to participation banking sector will effect the system positively.

The main aim in this study is to evaluate the participation banks by CAMELS rating system and examine the active participation banks comparatively between the years of 2015, when the first state participation bank emerged, and 2017. According to the result of analysis, however state participation banks have lower scores at some items of CAMELS system than the sector, it is seen that they have higher scores at the mean of CAMELS rating system.

Keywords: Participation banking, State participation banks, CAMELS rating system.

Jel Classification: G10, G21, M40.

Makale Gönderim Tarihi: 30.10 .2018

Makale Kabul Tarihi: 09.02.2019

Makale Türü: Araştırma makalesi

\footnotetext{
* Bu çalışma daha önce tam metin bildiri olarak 5. Uluslararası Muhasebe ve Finans Araştırmaları Kongresi'nde sunulmuştur.

** Dr. Öğr. Üyesi, Erzincan Üniversitesi, İktisadi ve İdari Bilimler Fakültesi, t.eyceyurt@ hotmail.com, ORCID ID: 0000-0003-4688-1811.
} 


\section{GİRIŞ}

Dünyada olduğu gibi Türkiye'de de faiz kullanan veya çalışmalarını faiz ile yürüten bankalar ile çalışmak istemeyen insanlar mevcuttur. Bu sebeple faiz ile çalışmayı reddeden bu kitleye yönelik, yastık altındaki paralarını da sisteme katmak adına 1971 yılında Mısır'da ilk İslami banka olan Nasser Social Bank kurulmuştur. Dünyadaki bu gelişmenin ardından Türkiye'de ilk İslami banka ise 1984 yılında kurulmuştur.

Türkiye'de İslami bankacılık “Özel Finans Kurumu” (ÖFK) adı altında ortaya çıkmıştır. 1984 yılında ilk ÖFK olan Albaraka Türk kurulmuş, 1989 yılında ise onu Kuveyt Türk takip etmiştir (Aysan vd. 2013: 103; Eyceyurt Batir ve Gungor, 2016: 75). Kuveyt Türk'ün ardından 1996 yılında Bank Asya, 2005 yılında ise Türkiye Finans Katılım Bankası (TFKB) kurulmuştur.

Özel Finans Kurumları 2005 yılında 5411 sayılı yeni Bankacılık Kanunu ile tamamen Bankacılık Düzenleme ve Denetleme Kurulu (BDDK) bünyesine alınmıştır. Böylece konvansiyonel bankalarla tamamen aynı nitelik ve önceliklere sahip olmuşlar ve ülkemizde daha fazla önem ve popülerlik kazanmışlardır. 5411 sayılı Bankacılık Kanunu'ndaki değişikliğe istinaden ÖFK ismi 2005 yılında "Katılım Bankası" olarak değiştirilmiştir(Aysan vd,2013: 99).

Türk Bankacılık Sistemi'nin toplam aktifindeki payı düşük olmasına rağmen kayda değer şekilde hızlı büyüme oranlarına sahip olması katılım bankalarının gelişen ve iyi işleyen finansal kurumlar olduğunu göstermektedir(Eyceyurt Batir vd, 2017: 86-87). Katılım bankaları 2002'de 1,8 milyar dolar olan aktiflerini ortalama \%33'lük yıllık büyüme oranı ile 2010 yılında 28 milyar dolara çıkarmıştır. Aynı dönemde sektörün yıllık genel büyüme ortalaması ise \%19 civarında gerçekleşmiştir. Bunun yanı sıra katılım bankaları 2002'de \%2,1 olan aktifteki pazar payını 2010 yılında \%4,3'e çıkarmıştır (Biçer, 2011: 2; Kartal ve Demir, 2017: 34).

2015 yılının Şubat ayında Tasarruf Mevduatı Sigorta Fonu (TMSF) katılım bankalarından Banka Asya'nın yönetiminin \%63'üne el koymuştur. 2015 yılı Mayıs ayında ise Bank Asya bazı finansal ve politik problemlerden dolayı tamamen TMSF'ye aktarılmıştır. İhlas Finans ve Bank Asya gibi katılım bankacılığındaki olumsuz tecrübeler, gerek katılım bankaları ile çalışan gerekse çalışmayan kişileri endişeye sevk etmiştir. Böylece devlet garantisi ve kamu temelindeki bankalar fikrine rağbet artmış, özellikle de katılım bankaları ile çalışan müssteriler kamu bazlı bankalar konusunda düşünmeye başlamışlardır. Son zamanlarda devlet de katılım bankalarının gelişmesini ve büyümesini amaçlamaktadır. Bu sebeple katılım bankalarını geliştirmek amacıyla bazı düzenlemelere gidilmiştir.

2016 yılı itibarıyla katılım bankalarının aktörlerinden biri olan Bank Asya'nın piyasadan çekilmesiyle, katılım bankası sayısı düşmüştür. Ancak bu düşüşün akabinde Ziraat Katılım ve Vakıf Katılım gibi kamu temelinde iki yeni katılım bankası faaliyete geçmiştir. Piyasaya yeni giren bu bankaların iki pozitif etkisi olmuştur. Birinci olarak katılım bankalarının sayısı artış göstermekte, ikinci olarak ise, devlet katılım bankacılığı sektörüne adım atmaktadır (Doğan, 2017: 1). 
Türkiye Katılım Bankaları Birliği (TKBB) başkanı ve Albaraka Türk genel müdürü Melikşah UTKU, 2017 Kasım ayında yaptığı röportajda, yeni kurulan kamu katılım bankalarının piyasaya öncelikle büyükşehirlerde gireceğini ancak kısa sürede Anadolu'daki taşra kesime odaklanacaklarını çünkü bu bölgelerde ciddi bir potansiyel olduğunu vurgulamaktadır (Utku, 2017: 1).

Bankalarda denetim mekanizması yaptıkları işin önemine binaen diğer işletmelerden çok daha yoğun işlemektedir. Özellikle bankaların denetimi amacıyla kullanılan ve finansal rasyoların değerlendirilmesi suretiyle işleyiş gösteren CAMELS metodu çalışmada tercih edilmiştir. Çalışmanın amacı, kamu katılım bankalarının ortaya çıktığı 2015 yılından itibaren katılım bankalarını CAMELS değerlendirme metodu ile değerlendirmek ve özellikle kamu katılım bankalarının bu sisteme ait kalemler konusunda sektöre nazaran ne derece başarılı olduğunu incelemektir.

CAMELS sistemi, Kaya (2001) tarafından denetim amaçlı, yerinde denetim ve uzaktan denetim aracı, Dincer, Gencer, Orhan, ve Sahinbas (2011) tarafından bankalar için önemli performans göstergelerinden biri, Roman and Şargu (2013) tarafindan bankacılık sistemin sağlamlığını gösteren en popüler yöntem, Nurazi ve Evans (2005) tarafindan banka aktiflerinin kalitesini denetlemek için kullanılan bir yöntem, Gilbert, Meyer, and Vaughan (2000) tarafından banka başarısızlıklarını öngörebilmek adına yararlı bir yöntem ve Kabir ve Dey (2012)'e göre ise bankacilık sektörü için bir derecelendirme sistemi olarak değerlendirilmiştir (Gümüş ve Nalbantoğlu, 2015: 86).

\section{LITERATÜR TARAMASI}

CAMELS metodu kullanılarak finansal performans ölçen çok sayıda ulusal ve uluslararası çalışma mevcuttur. Literatürde CAMELS analizi kullanılarak yapılan çalışmalardan bazıları aşağıda özet halinde verilmiştir.

Kaya (2001), 1997 ve 2000 yılları için Türk Bankacılık sistemini CAMELS analizi ile değerlendirmiş, 1997 yılında aktif büyüklüğü küçük bankaların daha iyi performans gösterdiğini, 2000 yılında ise bu durumun büyük bankalar lehine değiştiğini gözlemlemiştir. Çalışmada CAMELS performansları ve Tasarruf Mevduatı Sigorta Fonu (TMSF)'na alınma ilişkisi araştırılmış ve CAMELS notu yükseldikçe TMSF bünyesine alınma olasılığının düştüğü saptanmıştır.

Derviz ve Podpiera (2008), 1998-2001 ve 2002-2005 yılları arası Çek bankaları üzerinde çalışma yapmıştır. Çalışmada $\mathrm{S} \& \mathrm{P}$ ve CAMELS reyting sistemlerinin belirleyicileri tahmin edilmiştir. Bu tahmini yapmak için logit model ve panel veri analizi kullanılmıştır.

Sakarya (2010), hisse senetleri İstanbul Menkul Kıymetler Borsası (İMKB)'nda işlem gören yerli ve yabancı bankaların performansını 20052007 yılları arasında CAMELS sistemi ile analiz etmiştir. Analiz sonucunda sermaye yeterlilik oranlarının yabancı bankalarda yerli bankalara göre daha düşük olduğu, varlık kalitesinin yabancı bankalarda biraz daha yüksek olduğu, yönetim kalitesi olarak iki banka türünün neredeyse paralel olduğu, karlılık ve likidite açısından genel olarak yerli bankaların daha iyi oldukları ve piyasa riskine duyarlılık konusunda ise yabancı bankaların daha hassas oldukları belirlenmiştir. 
Roman and Şargu (2013), Romanya'da faaliyet gösteren 15 bankayı 2004-2011 yılları arasında CAMELS analizi kullanarak incelemiştir. 15 banka içerisinde en büyük olanının likidite haricindeki diğer kalemlerde iyi bir performans sergilediği tespit edilmiştir.

Rozzani and Rahman (2013), Malezya'da bulunan 19 konvansiyonel, 16 kat1lım bankasını 2008-2011 yılları arasında CAMELS analizi ile değerlendirmiştir. Çalışma sonucunda her iki banka türü için de performans sonuçlarının hemen hemen aynı olduğu görülmüştür.

Gümüş and Nalbantoğlu (2015), 2002-2013 yılları arasında kamu, özel yerli, yabanc1 ve katılım bankalarını 4 grup olarak karşılaştırmalı bir şekilde CAMELS analizi ile değerlendirmiştir. Araştırma sonucunda özel yerli bankalar birinci sırada, kamu bankaları ikinci sırada yer almıştır. Yabancı bankaların takip oranlarının artmasından dolayı karlılık ve yönetim kalitesi bakımından zayıf oldukları, katılım bankalarının ise sermayelerinin diğer banka türlerine göre zayıf kaldığı tespit edilmiştir.

Ege, Topaloğlu, and Karakozak (2015), çalışmalarında 2002-2010 dönemine ilişkin verileri kullanarak banka gruplarının karşılaştırmalı analizini yapmıştır. Elde edilen bulgulara göre sermaye yeterliliği, piyasa risklerine duyarlılık ve yönetim yeterliliği açısından kamu sermayeli mevduat bankalarının; karlılık açısından özel sermayeli mevduat bankalarının; aktif kalitesi ve likidite açısından ise yabancı sermayeli mevduat banklarının diğer banka gruplarına göre daha iyi durumda oldukları tespit edilmiştir.

Masood, Ghauri, and Aktan (2016), 2015 y1lında Pakistan'da faaliyet gösteren İslami bankalar üzerinde çalışmıştır. CAMELS analizinin kullanıldığı çalışmada bankalardan ikisinin tatmin edici seviyede oldukları, diğerlerinin ise vasat bir performans gösterdiği sonucuna varılmıştır.

Aspal and Dhawan (2016), Hindistan bankacılık sisteminde bir reyting aracı olarak kullanılan CAMELS modelinin parametrelerini literatür ve ampirik çalışmalar ışığında incelemiştir.

Yuksel, Dincer, and Hacioglu (2016), 2004-2014 yılları arasındaki yıllık verileri kullanarak Türkiye'de faaliyet gösteren 20 mevduat bankasını CAMELS analizi ile incelemiştir. Ardından Moody's den alınan bankalara ait kredi reytingleri ile CAMELS analizi arasındaki ilişki irdelenmiş, aktif kalitesi, yönetim kalitesi ve piyasa riskine duyarlılık kalemleri ile Moody's reytingleri arasında ilişki olduğu ancak sermaye yeterliliği ve karlılık ile Moody's reytingleri arasında anlamlı bir ilişki olmadığı sonucuna varılmıştır.

Yapılan incelemelerde ulusal bazda yapılan çalışmaların tamamına yakınının kamu, özel ve yabancı bankaların performansını karşılaşıırmak üzere yapıldığı ve katılım bankacılığına değinilmediği görülmüştür. Bu çalışmayı diğer çalışmalardan farklı ve özgün kılan, çalışmanın Türkiye'de bulunan katılım bankalarına yönelik ve yeni kurulan kamu katılım bankalarını değerlendirmek üzere yapılmasıdır. Bu da devlet sahipliğinde kurulan katılım bankalarının katılım bankacılı̆̆ı sektöründe nasıl bir performans sergilediğini görebilmek adına önem taşımaktadır.

\section{KAPSAM VE YÖNTEM}

Çalışmada, kamu katılım bankalarının ortaya çıkış yılı olan 2015 yılından sonra aktif olan katılım bankaları kullanılmıştır. Bu kapsamda aktif olan beş katılım bankası; Albaraka Türk, Kuveyt Türk, Türkiye Finans Katılım Bankası ile yeni kurulan Ziraat Katılım Bankası ve Vakıf Katılım Bankasıdır. Gerekli veriler TKBB ve BDDK'na ait web siteleri ve 
bankaların finansal tabloları kullanılmak suretiyle elde edilmiştir. Katılım bankalarının sayısının az olması ve kamu bankalarının yeni kurulması sebebiyle araştırmanın kapsadığı yılların sınırlı kalması araştırmanın kısıtını oluşturmaktadır.

Daha önce CAMEL adı ile bilinen metot ilk olarak 1979 yılında ABD'de banka düzenleyici kurumlar tarafından oluşturulmuştur. Ardından finansal kurumların sağlamlığını ölçmek için farklı ülkelerin denetim kurumlarının kullanabileceği faydalı bir araç olacağına karar verilmiş ve kullanım alanı genişletilmiştir. 1996 yılından itibaren riske odaklanılmış ve CAMEL yaklaşımına piyasa riskine karşı duyarlılık anlamına gelen " $S$ " (Sensitivity to market risk) kalemi de ilave edilerek yaklaşımın adı CAMELS olarak değiştirilmiştir (Roman ve Şargu, 2013). CAMELS, ABD'de denetim otoritelerince meydana getirilen, bankaların uzaktan gözetiminde ve denetimlerinde genel durumunu tespit etmekte kullanilan bir değerlendirme sistemidir. ABD'de yerinde denetim, risk bazlı işlemekte ve CAMELS reyting sistemi vasıtasıyla değerlendirilmektedir. Ancak bu sistem sadece yerinde denetim ile sinırlı kalmamakta uzaktan gözetim amacı ile de kullanılmaktadır (Kaya, 2001).

CAMELS metodu adını İngilizce bazı temel kavramların baş harflerinden almıştır. Bunlar; sermaye yeterliliği (Capital), aktif kalitesi (Asset), yönetim performansı (Management), karlılık durumu (Earning), likidite (Liquidity) ve piyasa riski (Sensitivity to market risk) kalemlerinden oluşmaktadır. Bu kalemler kısaca aşağıda tanımlanmış ve ardından Tablo 1'de bu kalemleri temsil etmek üzere kullanılan rasyolar hakkında bilgi verilmiştir:

- $\quad$ Sermaye Yeterliliği (C): Bankanın sermayesini miktar ve kalite açısından değerlendirmek amaciyla kullanılır. Sermaye yeterliliğini temsil etmek amacıyla çalışmada kullanılan rasyolar; sermaye yeterliliği rasyosu olarak da bilinen "Özkaynaklar / (Kredi + Piyasa + Operasyonel Riske Esas Tutar)" oranı, Özkaynaklar/Toplam aktifler oranı ve (Özkaynaklar - Duran aktif) / Toplam aktifler oranıdır.

- Aktif Kalitesi (A): Bankaların sahip oldukları varlıkların kalitesini ölçmek amacıyla kullanılır. Banka aktiflerinin gelir getirme gücünün, nakde dönüş kabiliyetinin ve işletmenin kaynak yapısına uygun olup olmadığının değerlendirildiği bir kalemdir(Ege et al., 2015). Aktif kalitesi ölçülürken kredi kullandırma becerileri, kredilerin geri dönüşü, problemli kredilerin varlığı ve tahsilat becerileri de göz önünde bulundurulmaktadır.

- Yönetim Kalitesi (M): Banka yönetiminin kapasite ve performansını temsil etmektedir. $\mathrm{Bu}$ kalemin hesaplanmasında bankaların yönetim bilgi sistemlerinin yapısı, mevzuata uygun işleyiş, iç kontrol sistemlerinin yeterliliği, sektördeki gelişmelerin takibi, yönetimin riskleri kontrol etme başarısı gibi kriterler göz önünde tutulur.

- Karlılık (E): Bankaların kazanç durumlarını değerlendirmek amacıyla kullanılır. Karlılık istikrarı, dağıtılmayan karlar ile yeterli sermayenin sağlanıp sağlanamadığı, karlılığın piyasa riskine duyarlılığı, kaynakları ve kalitesi gibi kriterlere dikkat edilmek suretiyle hesaplanmaktadir.

- Likidite (L): Bankaların nakde dönme becerilerini ölçmek amacıyla kullanılır. Likit kaynakların mevcut zaman ve gelecek için değerlendirilmesi, varlıkların menkul kıymete dönüştürülebilmesi, kısa vadeli fon kaynaklarına bağımlılık düzeyi ve para piyasaları benzeri piyasalara erişim imkanı gibi kriterler dikkate alınarak değerlendirilir.

- $\quad$ Piyasa Riskine Duyarlılık (S): Piyasada oluşabilecek kurlar, faiz oranları, mal fiyatları ve hisse senedi fiyatlarındaki değişiklikler gibi risklere karşı bankanın ne derece hazırlıklı olduğunu ölçmek amacıyla kullanılan kalemdir. Banka yönetiminin piyasada 
oluşabilecek riskleri tespit ve kontrol etmedeki başarısı, banka karlılığının piyasadaki olumsuzluklara karşı duyarlılığı, bankanın ticaret ve döviz işlemlerinden kaynaklanan piyasa riski durumu ve faiz riski yapısı gibi kriterlere dikkat edilmek suretiyle değerlendirilir.

Çalışmada her bir kalem için kullanılan rasyolar Tablo 1'de ilk sütunda gösterilmiştir. İkinci sütunda, kullanılan rasyoları temsil edecek kısaltmalar harflerle ifade edilmiştir. Üçüncü sütunda her bir rasyonun ana kalemlere etkilerinin olumlu veya olumsuz olmasına göre pozitif veya negatif şeklinde ilişki yönü belirtilmiştir. Son sütun olan ağıllık sütununda ise, her kaleme banka performansı üzerindeki etkileri dikkate alınarak farklı ağırlık oranları verilmiştir. Yine her bir kalemi oluşturan rasyolar da o kalem içerisindeki önemine göre ağırlıklandırılarak toplam CAMELS sistemine etkisi belirlenmiştir.

Tablo 1. Çalışmada Kullanılan Camels Rasyoları, İlişki Yönü ve Ağırlıkları

\begin{tabular}{|c|c|c|c|}
\hline & $\begin{array}{l}\text { Kisaltma } \\
\text { Adı }\end{array}$ & \begin{tabular}{|l} 
İlisiski \\
Yönü
\end{tabular} & Ağırlık \\
\hline CAPİTAL(Sermaye Yeterliliği) & & & 0,2 \\
\hline $\begin{array}{l}\text { Özkaynaklar / (Kredi + Piyasa + Operasyonel Riske Esas } \\
\text { Tutar) }\end{array}$ & $\mathrm{C} 1$ & + & 0,5 \\
\hline Özkaynaklar / Toplam Aktifler & $\mathrm{C} 2$ & + & 0,3 \\
\hline (Özkaynaklar - Duran Aktifler) / Toplam Aktifler & $\mathrm{C} 3$ & + & 0,2 \\
\hline ASSET (Aktif Kalitesi) & & & 0,2 \\
\hline Toplam Krediler ve Alacaklar / Toplam Aktifler & A1 & + & 0,4 \\
\hline Takipteki Krediler (net) / Toplam Krediler ve Alacaklar & A2 & - & 0,3 \\
\hline Duran Aktifler / Toplam Aktifler & A3 & - & 0,3 \\
\hline \begin{tabular}{|l|} 
MANAGEMENT (Yönetim) \\
\end{tabular} & & & 0,1 \\
\hline Takipteki Krediler (brüt) / Toplam Krediler ve Alacaklar & M1 & - & 0,4 \\
\hline Diğer Faaliyet Giderleri / Toplam Aktifler & M2 & - & 0,2 \\
\hline Şube Başına Kar & M3 & + & 0,2 \\
\hline Şube Başına Mevduat & M4 & + & 0,2 \\
\hline EARNING (Kar) & & & 0,2 \\
\hline Net Dönem Karı (Zararı) / Toplam Aktifler & E1 & + & 0,3 \\
\hline Net Dönem Karı (Zararı) / Özkaynaklar & E2 & + & 0,3 \\
\hline $\begin{array}{l}\text { Sürdürülen Faaliyeler Vergi Öncesi Kar (Zarar) / Toplam } \\
\text { Aktifler }\end{array}$ & E3 & + & 0,2 \\
\hline karpayı Dışı Gelirler (net) / Diğer Faaliyet Giderleri & E4 & + & 0,2 \\
\hline LIQUIDITY (Likidite) & & & 0,2 \\
\hline Likit Aktifler / Toplam Aktifler & L1 & + & 0,4 \\
\hline Likit Aktifler / Kısa Vadeli Yükümlülükler & L2 & + & 0,3 \\
\hline Türk Parası (TP) Likit Aktifler / Toplam Aktifler & L3 & + & 0,3 \\
\hline $\begin{array}{l}\text { SENSITIVITY TO MARKET RISK (Piyasa Riskine } \\
\text { Duyarlılık) }\end{array}$ & & & 0,1 \\
\hline YP Aktifler / YP Pasifler & S1 & - & 0,4 \\
\hline $\begin{array}{l}\text { Özel Karşılıklar Sonrası Net karpayı Geliri / Toplam } \\
\text { Aktifler }\end{array}$ & S2 & + & 0,3 \\
\hline Döviz Poz/Özkaynaklar & S3 & $1-$ & 0,3 \\
\hline
\end{tabular}


CAMELS performans değerlerini hesaplayabilmek için CAMELS değerlendirme sistemini oluşturan 6 ana kaleme ait 20 adet rasyodan faydalanılmıştır. Öncelikle TKBB web sitesinde ilan edilen, bankaların Tablo 1'de belirtilen rasyoları esas alınarak ortalamalar hesaplanmış böylece 2015-2017 y1llarına ait katılım bankacılık sektörünün referans değerleri bulunmuştur. Ardından o dönem faaliyet gösteren her bir katılım bankasının aynı dönemlere ait gerçekleşen değerleri tespit edilmiştir. Daha sonra her bankaya ait gerçekleşen değerler referans değerlerine bölünerek 100 ile çarpılmış, böylece endeks değer elde edilmiş, bu endeks değerler değişkenin ilişki yönüne göre pozitif ilişkiye sahip ise elde edilen endeks değerden 100 çıkarılmış, negatif ilişkiye sahip ise 100'den endeks değer çıkarılarak sapma değer hesaplanmıştır. Bu aşama sonrasında her bir sapma değer, kendisine ait değişkenin ağırlık oranı ile çarpılarak her bir kaleme ait CAMELS analizinde kullanılacak değerler hesaplanmıştır. Çarpım sonrasında elde edilen sonuçlar her bir kalem kapsamında toplanmıştır. Elde edilen her toplam, ilgili bileşenin CAMELS puanını ortaya çıkarmış ve CAMELS sistemini meydana getiren her bir kalem için belirlenen katsayılar, ilgili kalemin notu ile çarpılmış ve bu çarpımların toplanması ile elde edilen sonuç CAMELS değerlendirme sistemindeki performansını vermiştir. Hesaplama süreci Tablo 2'de kısaca özetlenmiştir.

Tablo 2. CAMELS Performans Sistemi Örnek Hesaplama Tablosu

\begin{tabular}{|l|l|l|l|l|l|l|l|}
\hline Değişkenler & $\begin{array}{l}\text { İlişkinin } \\
\text { Yönü }\end{array}$ & Ağırlık & $\begin{array}{l}\ldots \text { Yılı } \\
\text { Referans } \\
\text { Değer }\end{array}$ & $\begin{array}{l}\text { Banka } \\
\text { Adı }\end{array}$ & $\begin{array}{l}\text { Endeks } \\
\text { Değer }\end{array}$ & $\begin{array}{l}\text { Sapma } \\
\text { Değer }\end{array}$ & $\begin{array}{l}\text { Camels } \\
\text { Değeri }\end{array}$ \\
\hline $\begin{array}{l}\text { Özkaynaklar } \\
\text { / Toplam } \\
\text { Aktifler }\end{array}$ & + & 0,3 & $\mathrm{~A}$ & $\mathrm{X}$ & $\begin{array}{l}100^{*}(\mathrm{X} / \mathrm{A}) \\
=\mathrm{C}\end{array}$ & $\begin{array}{l}\mathrm{C}-100 \\
=\mathrm{E}\end{array}$ & $\mathrm{E}^{*} 0,3$ \\
\hline $\begin{array}{l}\text { Diğer } \\
\text { Faaliyet } \\
\text { Giderleri / } \\
\text { Toplam } \\
\text { Aktifler }\end{array}$ & - & 0,2 & $\mathrm{~B}$ & $\mathrm{Y}$ & $\begin{array}{l}100^{*}(\mathrm{Y} / \mathrm{B}) \\
=\mathrm{D}\end{array}$ & $\begin{array}{l}100-\mathrm{D} \\
=\mathrm{F}\end{array}$ & $\mathrm{F}^{*} 0,2$ \\
\hline
\end{tabular}

\section{ARAȘTIRMANIN BULGULARI}

Çalışmada CAMELS analizi kapsamında Tablo 2'de tarif edilen basamaklar sırasıyla uygulanmış ve her bir katılım bankasının CAMELS sistemine dair kalemleri hesaplanmıştır. $\mathrm{Bu}$ kalemleri oluşturan rasyolar ve kalemlere ait toplam puan her bir y1la ve her bankaya göre detaylı olarak Tablo 3'te verilmiştir.

Son olarak tüm kalemlere ait notlar Tablo 1'de verilen ağırlıkları nispetinde toplanarak her bankaya ait bileşik CAMELS notu hesaplanmıştır. Bileşik CAMELS notları detaylı olarak Tablo 4'de sunulmuştur. 
Tablo 3. Katılım Bankalarının Yıllara göre CAMELS Analizinde Kullanılan Puanları

\begin{tabular}{|c|c|c|c|c|c|c|c|c|c|c|c|c|c|c|c|}
\hline & \multicolumn{3}{|c|}{ Albaraka Türk } & \multicolumn{3}{|c|}{ Kuveyt Türk } & \multicolumn{3}{|c|}{ TFKB } & \multicolumn{3}{|c|}{ Vakıf Katılım } & \multicolumn{3}{|c|}{ Ziraat Katılım } \\
\hline & 2015 & 2016 & 2017 & 2015 & 2016 & 2017 & 2015 & 2016 & 2017 & 2015 & 2016 & 2017 & 2015 & 2016 & 2017 \\
\hline \multicolumn{16}{|l|}{ Sermaye } \\
\hline $\mathrm{C} 1$ & $-15,95$ & $-12,15$ & 13,51 & \begin{tabular}{|l|}
$-18,58$ \\
\end{tabular} & 1,06 & 15,74 & $-20,17$ & $-6,19$ & 17,82 & - & 32,25 & 2,45 & 54,69 & $-14,96$ & $-49,52$ \\
\hline $\mathrm{C} 2$ & $-14,32$ & $-10,29$ & $-6,37$ & $-12,16$ & $-7,07$ & $-2,26$ & $-10,81$ & $-3,17$ & 5,89 & - & 23,22 & $-1,05$ & 37,29 & $-2,69$ & 3,79 \\
\hline $\mathrm{C} 3$ & $-11,06$ & $-11,07$ & $-7,52$ & $-8,84$ & $-4,23$ & 2,40 & $-15,66$ & $-15,96$ & $-15,39$ & - & 27,54 & 8,07 & 35,55 & 3,72 & 12,43 \\
\hline SERMAYE Notu & $-41,33$ & $-33,50$ & $-0,38$ & $-39,57$ & $-10,24$ & 15,88 & $-46,64$ & $-25,32$ & 8,33 & - & 83,01 & 9,47 & 127,54 & \begin{tabular}{|l|}
$-13,94$ \\
\end{tabular} & $-33,30$ \\
\hline Aktif & & & & & & & & & & - & & & & & \\
\hline $\mathrm{A} 1$ & $-3,06$ & 1,07 & $-1,12$ & $-3,82$ & $-3,80$ & $-3,66$ & 1,21 & 0,74 & $-2,66$ & - & $-1,13$ & 1,79 & 5,67 & 3,12 & 5,65 \\
\hline A2 & 16,38 & $-0,20$ & 3,72 & 23,53 & 22,86 & 28,37 & $-69,91$ & $-80,15$ & $-89,95$ & - & 28,87 & 29,62 & 30,00 & 28,62 & 28,24 \\
\hline $\mathrm{A} 3$ & 8,00 & $-4,04$ & $-2,02$ & 9,17 & 8,70 & 12,27 & $-24,33$ & $-43,93$ & $-55,13$ & - & 17,82 & 23,37 & 7,17 & 21,44 & 21,51 \\
\hline AKTİF NOTU & 21,32 & $-3,17$ & 0,58 & 28,87 & 27,76 & 36,97 & $-93,04$ & $-123,34$ & $-147,74$ & - & 45,56 & 54,79 & 42,84 & 53,19 & 55,40 \\
\hline Yönetim & & & & & & & & & & - & & & & & \\
\hline M1 & $-5,51$ & $-35,35$ & $-36,33$ & 9,12 & 0,83 & 9,47 & $-43,61$ & $-41,01$ & $-46,04$ & - & 38,21 & 37,53 & 40,00 & 37,32 & 35,37 \\
\hline M2 & 1,98 & $-1,77$ & $-4,13$ & 0,51 & $-2,35$ & $-2,35$ & 2,96 & $-1,19$ & $-3,50$ & - & 2,41 & 4,37 & $-5,44$ & 2,90 & 5,62 \\
\hline M3 & 6,01 & 1,88 & $-7,73$ & 2,66 & 9,98 & $-0,76$ & 1,37 & 2,18 & $-5,21$ & - & $-8,03$ & 4,97 & $-10,04$ & $-6,02$ & 8,73 \\
\hline M4 & 4,77 & 2,94 & $-1,15$ & 0,31 & $-2,61$ & \begin{tabular}{|l|}
$-3,64$ \\
\end{tabular} & 0,11 & $-4,46$ & $-7,51$ & - & $-1,17$ & 6,23 & $-5,19$ & 5,30 & 6,07 \\
\hline YÖNETIMM NOTU & 7,25 & \begin{tabular}{|l|}
$-32,30$ \\
\end{tabular} & $-49,34$ & 12,60 & 5,85 & 2,72 & $-39,17$ & $-44,47$ & $-62,27$ & - & 31,43 & 53,10 & 19,33 & 39,50 & \begin{tabular}{|l|}
55,79 \\
\end{tabular} \\
\hline Karlılık & & & & & & & & & & - & & & & & \\
\hline E1 & 25,89 & $-0,09$ & \begin{tabular}{|l|}
$-10,18$ \\
\end{tabular} & 27,53 & 20,30 & 5,67 & 6,71 & 4,44 & $-0,73$ & - & $-11,87$ & 1,71 & $-60,14$ & $-12,78$ & 3,54 \\
\hline E2 & 21,67 & 8,02 & $-4,98$ & 16,89 & 25,19 & 8,46 & $-2,10$ & 2,20 & $-5,79$ & - & \begin{tabular}{|l|}
$-21,39$ \\
\end{tabular} & 2,65 & $-36,46$ & $-14,02$ & $-0,34$ \\
\hline E3 & 14,91 & $-0,86$ & $-7,07$ & 16,01 & 12,54 & 4,22 & 3,64 & 2,73 & $-0,85$ & - & $-6,36$ & 0,95 & $-34,57$ & $-8,04$ & 2,75 \\
\hline E4 & 6,83 & 0,69 & $-6,04$ & 10,00 & 4,33 & 1,70 & 0,66 & 8,71 & $-0,52$ & - & $-0,86$ & 16,54 & $-17,48$ & $-12,86$ & $-11,69$ \\
\hline KAR NOTU & 69,30 & 7,75 & $-28,27$ & \begin{tabular}{|l|}
70,44 \\
\end{tabular} & 62,36 & 20,06 & 8,91 & 18,08 & $-7,90$ & - & $-40,49$ & 21,85 & $-148,65$ & $-47,70$ & $-5,74$ \\
\hline
\end{tabular}


Tablo 3. (Devami)

\begin{tabular}{|c|c|c|c|c|c|c|c|c|c|c|c|c|c|c|c|}
\hline & \multicolumn{3}{|c|}{ Albaraka Türk } & \multicolumn{3}{|c|}{ Kuveyt Türk } & \multicolumn{3}{|l|}{ TFKB } & \multicolumn{3}{|c|}{ Vakıf Katılım } & \multicolumn{3}{|c|}{ Ziraat Katılım } \\
\hline & 2015 & 2016 & 2017 & 2015 & 2016 & 2017 & 2015 & 2016 & 2017 & 2015 & 2016 & 2017 & 2015 & 2016 & 2017 \\
\hline Likidite & & & & & & & & & & - & & & & & \\
\hline L1 & 5,69 & $-4,10$ & 2,31 & 11,51 & 7,39 & 7,96 & $-7,21$ & $-6,18$ & 1,36 & - & 6,99 & 1,20 & $-9,99$ & $-4,09$ & $-12,82$ \\
\hline $\mathrm{L} 2$ & 3,85 & $-6,09$ & $-0,25$ & 5,75 & 1,53 & 5,08 & $-4,84$ & $-4,55$ & 4,42 & - & 14,44 & 0,30 & $-4,77$ & $-5,33$ & $-9,54$ \\
\hline L3 & 6,04 & $-4,03$ & 5,57 & $-4,52$ & $-12,49$ & $-8,61$ & $-8,69$ & $-11,80$ & $-4,94$ & - & 15,00 & 13,71 & 7,17 & 13,32 & $-5,74$ \\
\hline LIKIIDİTE NOTU & 15,57 & $-14,22$ & 7,63 & 12,75 & $-3,57$ & 4,43 & $-20,74$ & $-22,53$ & 0,84 & - & 36,43 & 15,21 & $-7,58$ & 3,90 & $-28,11$ \\
\hline Piyasa Riski & & & & & & & & & & - & & & & & \\
\hline S1 & $-1,03$ & 7,98 & 0,33 & $-6,19$ & $-3,11$ & $-2,52$ & 33,28 & 11,62 & 11,85 & - & $-29,43$ & $-8,44$ & $-4,40$ & 12,70 & 3,91 \\
\hline S2 & 0,78 & 0,87 & 1,59 & 0,91 & 7,11 & 3,59 & 31,59 & $-2,35$ & $-3,65$ & - & $-5,21$ & $-11,64$ & 0,66 & 0,87 & 4,87 \\
\hline S3 & $-1,91$ & $-12,58$ & $-1,96$ & $-0,50$ & 16,82 & 0,09 & 39,27 & $-21,17$ & $-11,71$ & - & 20,49 & 17,21 & 23,58 & $-13,01$ & $-6,07$ \\
\hline PIYASA RİSKİ & $-2,16$ & $-3,72$ & $-0,04$ & $-5,78$ & 20,82 & 1,16 & 104,14 & $-11,89$ & $-3,51$ & - & $-14,15$ & $-2,87$ & 19,83 & 0,56 & 2,70 \\
\hline
\end{tabular}

Tablo 4. 2015-2017 Yı1ları Arasında Katılım Bankaları Bazında Hesaplanan Bileşik CAMELS Notları

\begin{tabular}{|c|c|c|c|c|c|c|c|c|c|c|c|c|c|c|c|c|}
\hline & & \multicolumn{3}{|c|}{ Albaraka Türk } & \multicolumn{3}{|c|}{ Kuveyt Türk } & \multicolumn{3}{|l|}{ TFKB } & \multicolumn{3}{|c|}{ Vakıf Katılım } & \multicolumn{3}{|c|}{ Ziraat Katılim } \\
\hline $\begin{array}{l}\text { CAMELS } \\
\text { Kalemler }\end{array}$ & Ağırlık & 2015 & 2016 & 2017 & 2015 & 2016 & 2017 & 2015 & 2016 & 2017 & 2015 & 2016 & 2017 & 2015 & 2016 & 2017 \\
\hline SERMAYE & 0,2 & $-41,33$ & $-33,50$ & $-0,38$ & $-39,57$ & $-10,24$ & 15,88 & $-46,64$ & $-25,32$ & 8,33 & - & 83,01 & 9,47 & 127,54 & $-13,94$ & $-33,30$ \\
\hline AKTİF & 0,2 & 21,32 & $-3,17$ & 0,58 & 28,87 & 27,76 & 36,97 & $-93,04$ & $-123,34$ & $-147,74$ & - & 45,56 & 54,79 & 42,84 & 53,19 & 55,40 \\
\hline YÖNETIMM & 0,1 & 7,25 & $-32,30$ & $-49,34$ & 12,60 & 5,85 & 2,72 & $-39,17$ & $-44,47$ & $-62,27$ & - & 31,43 & 53,10 & 19,33 & 39,50 & 55,79 \\
\hline KAR & 0,2 & 69,30 & 7,75 & $-28,27$ & 70,44 & 62,36 & 20,06 & 8,91 & 18,08 & $-7,90$ & - & $-40,49$ & 21,85 & $-148,65$ & $-47,70$ & $-5,74$ \\
\hline LIKIIDİTE & 0,2 & 15,57 & $-14,22$ & 7,63 & 12,75 & $-3,57$ & 4,43 & $-20,74$ & $-22,53$ & 0,84 & - & 36,43 & 15,21 & $-7,58$ & 3,90 & $-28,11$ \\
\hline $\begin{array}{l}\text { PIYYASA } \\
\text { RİSKI }\end{array}$ & 0,1 & $-2,16$ & $-3,72$ & $-0,04$ & $-5,78$ & 20,82 & 1,16 & 104,14 & $-11,89$ & $-3,51$ & - & $-14,15$ & $-2,87$ & 19,83 & 0,56 & 2,70 \\
\hline $\begin{array}{l}\text { ORT. } \\
\text { CAMELS }\end{array}$ & 1 & 13,48 & $-12,23$ & $-9,025$ & 15,17 & 17,92 & 15,85 & $-23,80$ & $-36,25$ & $-35,87$ & - & 26,62 & 25,28 & 6,74 & 3,09 & 3,50 \\
\hline
\end{tabular}


Tablo 3'de verilen veriler CAMELS' 1 oluşturan her bir kalem bazında ayrı ayrı grafik haline getirilmiş ve görsel olarak daha kolay anlaşılır hale getirilmeye çalışılmış̧ır. Bu kapsamda Grafik 1 - Grafik 7 arası yedi adet grafik oluşturularak yorumlanmıştır.

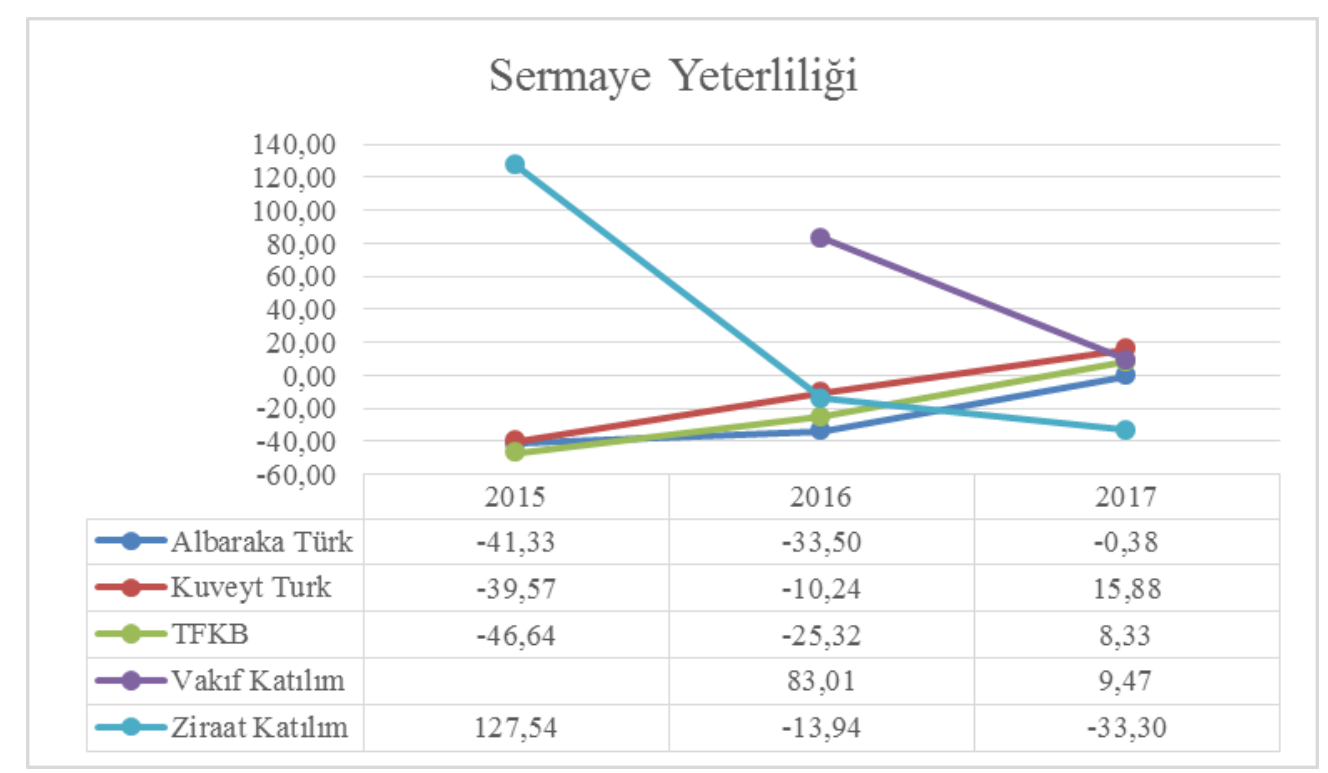

Grafik 1. 2015-2017 Yılları Arası Herbir Katılım Bankasına ait Sermaye Yeterliliği

Grafik 1'de 2015 - 2017 ylları arasında katılım bankalarının sermaye yeterliliği hesaplanarak grafik halinde gösterilmiştir. Bu kalem sermaye miktar ve kalitesini ölçerek bankaların sermaye gücüne dair bilgi vermektedir. Bankaların sermaye yeterliliğini hesaplamak üzere literatür ve TBB ile TKBB'nin kalemle ilgili sunmuş olduğu rasyolar dikkate alınarak, "Özkaynaklar / (Kredi + Piyasa + Operasyonel Riske Esas Tutar), Özkaynaklar / Toplam Aktifler, (Özkaynaklar - Duran Aktifler) / Toplam Aktifler" rasyoları tercih edilmiştir. Tablo 1'de verilen ağırlıklar dikkate alınarak ilgili rasyolar sırasıyla yüzde 50 , yüzde 30 ve yüzde 20 ağırlık oranlarıyla çarpılarak toplam alınmış ve CAMELS'a ait sermaye yeterliliği kalemi hesaplanmıştır. Sektör ortalamasının CAMELS notu payının sıfır olduğu dikkate alınırsa, Albaraka Türk'ün sermaye yeterliliği konusunda her üç yılda da sektör ortalamasının altında kalarak negatif not aldığı, Kuveyt Türk ve TFKB'nin 2015 ve 2016 yılında negatif, 2017 yılında pozitif değer aldığı, 2016'da faaliyete başlayan Vakıf Katılım Bankası'nın aktif olduğu her iki yıl için de pozitif değer alarak sermaye yapısını sağlam tuttuğu söylenebilir. Son olarak Ziraat Katılım Bankasının ise ilk faaliyet gösterdiği 2015 yılında pozitif bir sermaye notuna sahipken 2016 ve 2017 yllarında negatif nota sahip olduğu görünmektedir. Grafik incelendiğinde her iki kamu katılım bankasının da ilk kuruluş yılında sağlam bir sermaye yapısı ile kurulduğunu daha sonra bu durumun zayıflamaya başladığı görülmektedir. Ancak 2017 yılında Ziraat Katılım haricindeki hemen her katılım bankasının sermaye yapısının pozitif ve sağlam olduğu ve sadece Ziraat Katılımın sektör ortalamasının altında kalarak negatif bir nota sahip olduğu görülmektedir. 


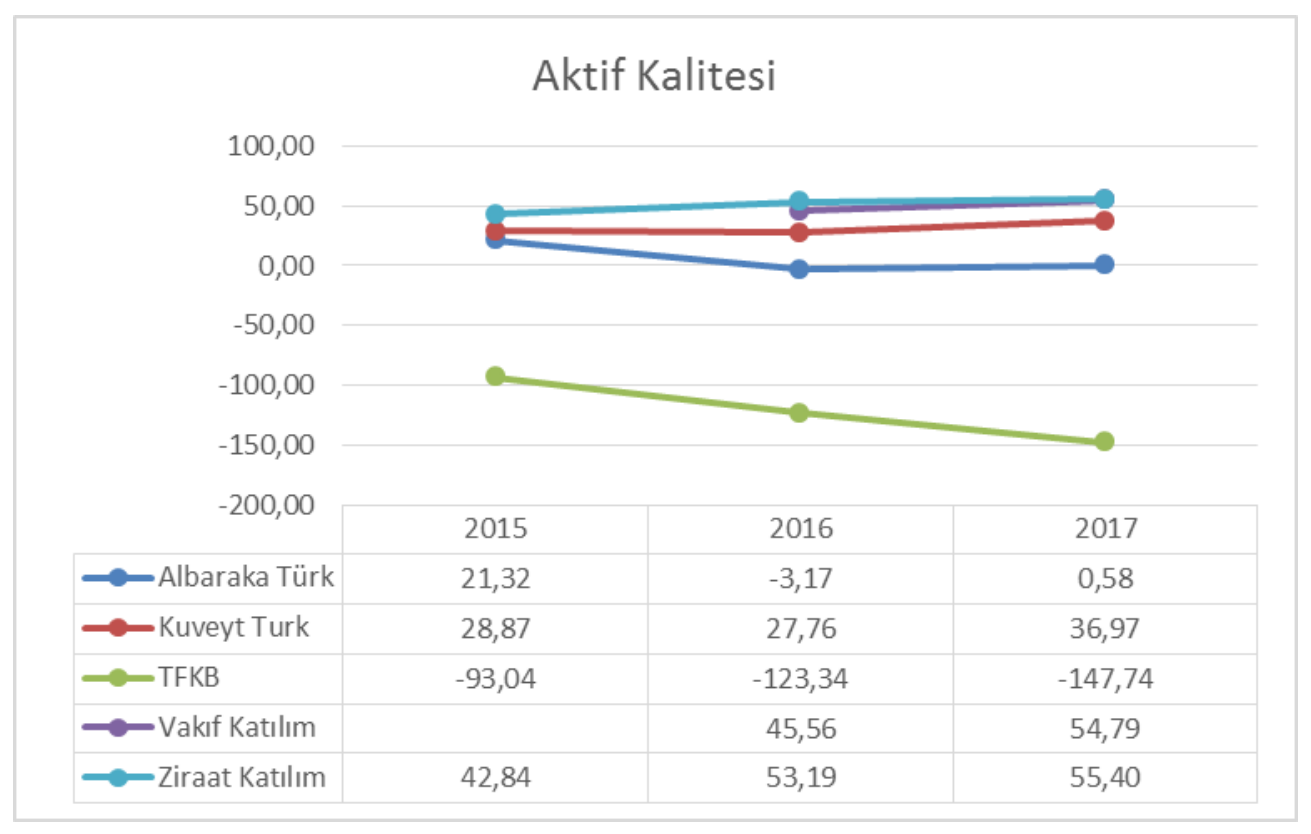

Grafik 2. 2015 - 2017 Yılları Arası Her Bir Katılım Bankasına ait Aktif Kalitesi

Aktif kalitesi kalemi bankalara ait varlıkların kalitesini ölçmek amacıyla kullanılır. Banka aktiflerinin gelir getirme gücünün, nakde dönüş kabiliyetinin ve işletmenin kaynak yapısına uygun olup olmadığının değerlendirildiği bu kalem için literatür bilgisi ve TKBB'nin sunmuş olduğu rasyolar da dikkate alınarak, Toplam krediler ve alacaklar / Toplam aktifler, Takipteki krediler (net) / Toplam krediler ve alacaklar, Duran aktifler / Toplam aktifler rasyoları kullanılmıştır. Sırasıyla yüzde 40, yüzde 30 ve yüzde 30 ağırlık oranları kullanılarak hesaplanan kalem notu ile aktif kalitesi ölçülürken kredi kullandırma becerileri, kredilerin geri dönüşü, problemli kredilerin varlığı ve tahsilat becerileri değerlendirilir. Grafik verileri incelendiğinde TFKB dışındaki tüm katılım bankalarının hemen her yıla ait notlarının pozitif olduğu, TFKB'nin ise aktif kalitesi göstergelerinin son y1llarda daha da kötüleşmek suretiyle hep negatif olduğu görülmektedir. $\mathrm{Bu}$ durum diğer katılım bankalarının aktiflerinin gelir getirme gücünün yüksek olduğu ancak TFKB'nin kredi tahsilatında ve takipteki krediler konusunda problemleri olabileceği şeklinde yorumlanabilir. Yeni kurulan kamu katılım bankalarının ise sektör içinde en yüksek aktif kalitesi notuna sahip oldukları görülmektedir. $\mathrm{Bu}$ durum bankaların yeni kurulması sebebiyle sorunlu kredilerinin diğer bankalara göre daha az olmasından kaynaklanabilir. 


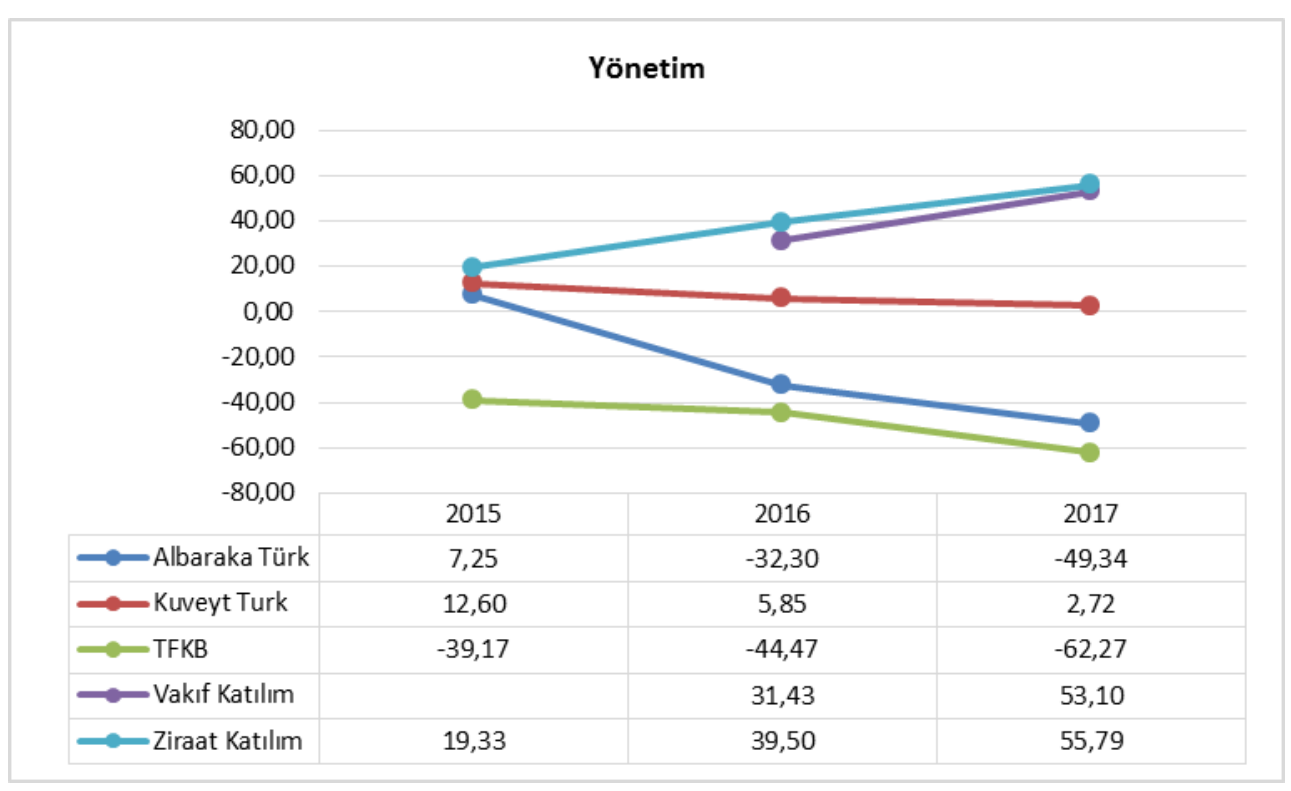

Grafik 3. 2015 - 2017 Yılları Arası Herbir Katılım Bankasına ait Yönetim Performans1

Banka yönetiminin kapasite ve performansını temsil eden bu kalem için literatür takip edilerek Takipteki krediler / Toplam krediler ve alacaklar, Diğer faaliyet giderleri / Toplam aktifler, Şube başına kar, Şube başına mevduat rasyoları kullanılmıştır. Sırasıyla yüzde 40, yüzde 20 , yüzde 20 ve yüzde 20 ağırlık payları kullanılarak her bir rasyo ağırlık değerleriyle çarpılmış ve toplamları alınarak kaleme ait yönetim notu hesaplanmıştır. Bu kalem, bankaların yönetim bilgi sistemlerinin yapısı, mevzuata uygun işleyiş, iç kontrol sistemlerinin yeterliliği, sektördeki gelişmelerin takibi, yönetimin riskleri kontrol etme başarısı gibi konularda bilgi verir. Grafik incelendiğinde en yüksek notların kamu katılım bankalarına ait olduğu, Kuveyt Türk'ün de her yıl için yönetim performans notunun sektör ortalamasının üzerinde olduğu görülmektedir. Albaraka Türk 2015 yllında pozitif nota sahipken 2016 ve 2017 yıllarında negatif notlar almış, TFKB ise analizin yapıldığ 1 her üç yıl için de negatif puan almıştır. Bu durum Albaraka Türk ve TFKB'nin yönetimlerinin sektör ortalamasına göre başarısız olduğuna dair bir işaret olabilir. Yönetim performansı konusunda en yüksek puanı alan kamu katılım bankalarının yeni kurulması sebebiyle şube sayılarının az olması ve takipteki kredilerinin az olması bu kalemde yüksek not almalarına sebep olmuş olabilir. 


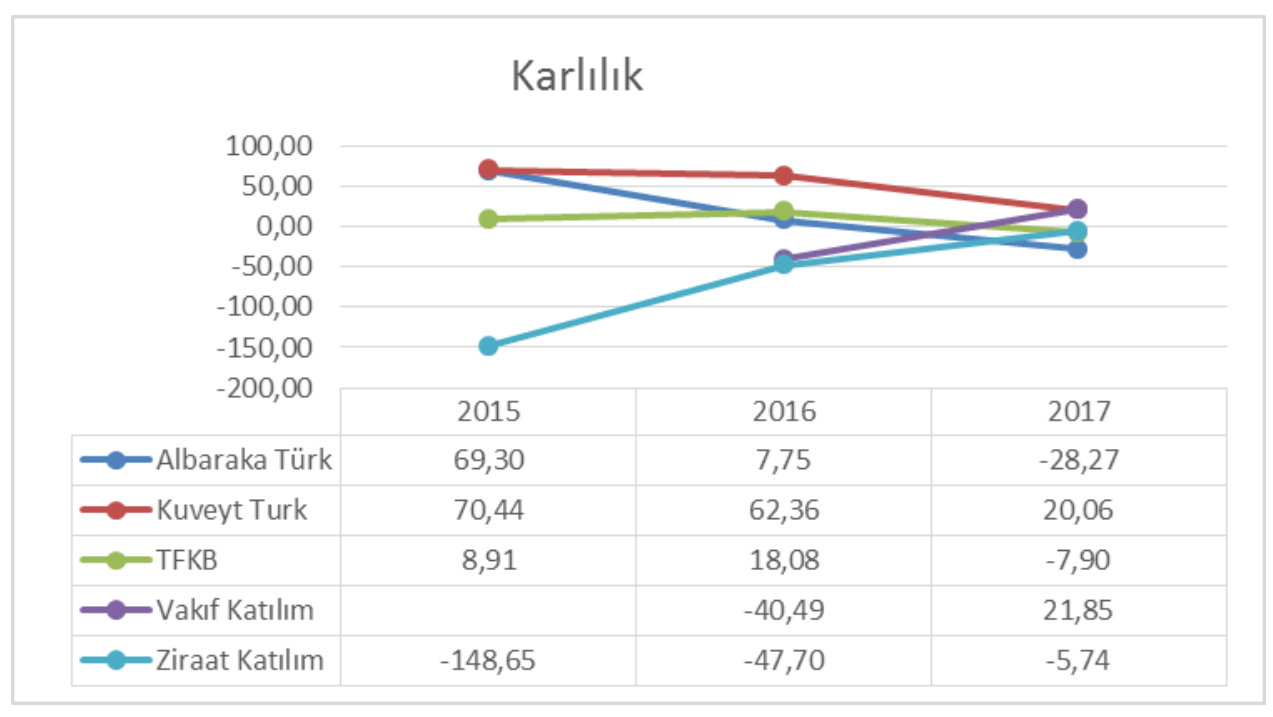

Grafik 4. 2015-2017 Y1lları Arası Her bir Katılım Bankasına ait Karlılık Durumu

Bankaların kazanç durumlarını değerlendirmek amacıyla kullanılan bu kalemde literatürün takip edilmesiyle "Net dönem karı / Toplam aktifler, Net dönem karı / Özkaynaklar, Vergi öncesi kar / Toplam aktifler, Karpayı dışı gelirler / Diğer faaliyet giderleri" rasyoları kullanılmıştır. Sırasıyla yüzde 40, yüzde 30 , yüzde 30 ağırlık oranları kullanılarak hesaplanan kalem; karlılık istikrarı, karlılığın piyasa riskine duyarlılığ kaynakları ve kalitesi gibi konularda bilgi vermektedir. Grafik incelendiğinde en yüksek karlı1ık rasyolarının Kuveyt Türk'e ait olduğu görünmektedir. Albaraka Türk ve TFKB'nin 2015 ve 2016 yıllarında sektör ortalamasının üzerinde bir nota sahip olduğu ancak 2017 yılında her iki bankanın da karlılık rasyolarının sektör ortalamasının altına düştüğü görülmektedir. Kamu katılım bankalarının her ikisinin de özellikle ilk kuruluş yıllarında sektörün oldukça altında karlılık rasyolarına sahip olduğu görünmektedir. Sonraki yıllarda bu görünüm pozitife doğru ilerlemiştir. Bu durumun sebebi bankaların yeni kurulması sebebiyle kuruluş maliyetlerinin yüksek olması ve ilk yıllarda zarar etmelerinden kaynaklanmış olabilir. Ancak belirtildiği üzere kamu katılım bankaları için görünüm her yıl olumlu bir seyir izleyerek pozitife doğru ilerlemektedir. 


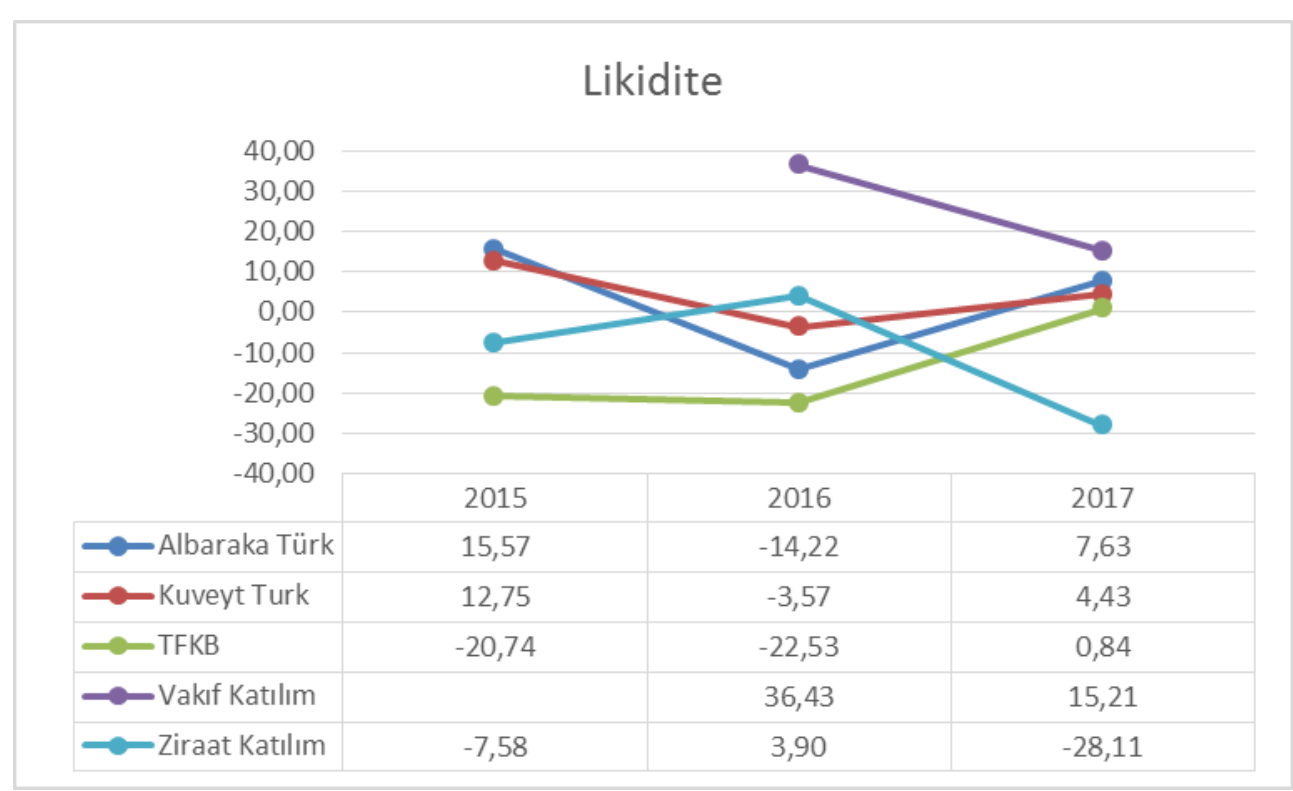

Grafik 5. 2015 - 2017 Yılları Arası Her bir Katılım Bankasına ait Likidite Durumu

Bankaların nakde dönme becerilerini ölçmek amacıyla kullanılan bu kalemin hesaplanmasında literatürün takip edilmesiyle Likit aktifler / Toplam aktifler, Likit aktifler / Kısa vadeli yükümlülükler, TP (Türk Parası) likit aktifler / Toplam aktifler rasyoları tercih edilmiştir. Sırasıyla yüzde 40, yüzde 30 ve yüzde 30 ağırlık oranlarının kullanılmasıyla hesaplanan bu kalem; likit kaynakların mevcut zaman ve gelecek için değerlendirilmesi, varlıkların menkul kıymete dönüştürülebilmesi gibi konularda bilgi vermektedir. Grafik 5 incelendiğinde, eski özel katılım bankaları olan Albaraka Türk, Kuveyt Türk ve TFKB'nin her üçünün de 2015 yılında daha sağlam bir likiditeye sahipken 2016' da likiditelerinin sektör ortalamasının altına düştüğü, 2017 yılında ise tekrar sektör ortalamasının üzerine çıkarak likiditelerini sağlamlaştırdıkları görülmektedir. Kamu katılım bankalarından Vakıf Katılım aktif olduğu 2016 ve 2017 yıllarının her ikisinde de sektör ortalamasına göre daha yüksek likidite oranlarına sahip olmuştur. Ziraat Katılım ise özel katılım bankalarının aksine 2015 yılında sektöre göre düşük bir likidite notuna sahip olmuş, 2016 yılında "3,90" ile likiditesini sağlamlaştırmış, ancak 2017 yılında likiditesinde ciddi bir düşüş göstererek sektör içerisinde en düşük likidite notuna sahip olan banka olmuştur. Bu durum bankanın likit varlıklarının azalmasından veya toplam aktiflerinin artmasından kaynaklanmış olabilir. 


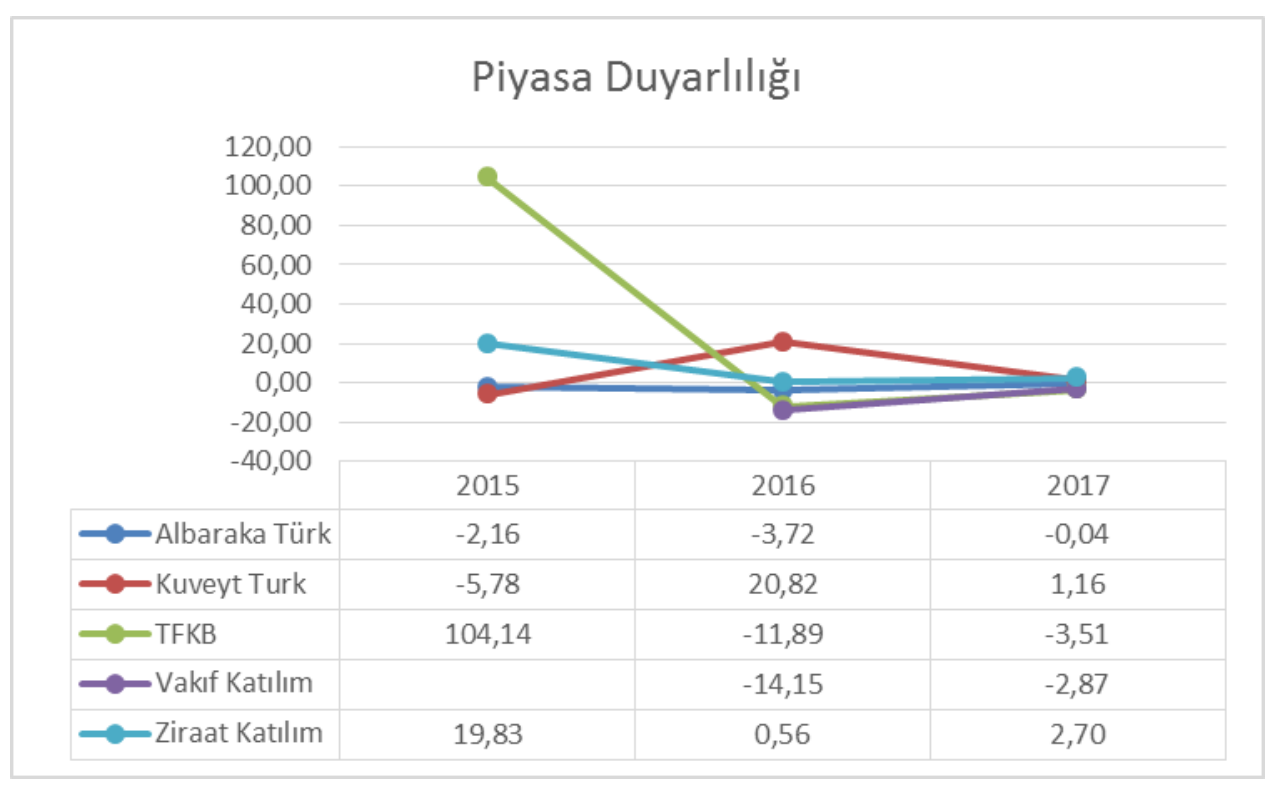

Grafik 6. 2015 - 2017 Y1lları Arası her bir Katılım Bankasına ait Piyasa Duyarlılığı

Piyasa duyarlılığı kalemi, piyasada oluşabilecek kurlar, faiz oranları, mal fiyatları ve hisse senedi fiyatlarındaki değişiklikler gibi risklere karşı bankanın ne derece hazırlıklı olduğunu ölçmek amacıyla kullanılan bir kalemdir. Kalemin hesaplanmasında kullanılmak üzere literatüre istinaden YP (Yabancı Para) aktifler / YP pasifler, Özel karşılıklar sonrası net karpayı geliri / Toplam aktifler, Döviz pozisyonu / Özkaynaklar rasyoları seçilmiştir. TKBB'nin web sitesinde döviz pozisyonu rasyosu bulunmadığından ilgili rasyo bankaların finansal tablolarını kullanmak suretiyle hesaplanmıştır. Sırasıyla rasyolar için yüzde 40, yüzde 30 ve yüzde 30 ağırlık oranlarının kullanıldığı kalem banka yönetiminin piyasada oluşabilecek riskleri tespit ve kontrol etmedeki başarısı, banka karlılığının piyasadaki olumsuzluklara karşı duyarlılığı, bankanın ticaret ve döviz işlemlerinden kaynaklanan piyasa riski durumu ve faiz riski yapısı gibi konularda öngörü sağlamaktadır. Grafik incelendiğinde en yüksek notun 2015 yılında “104,14”ile TFKB'de olduğu görülmektedir. Bu durum, 2015 yılında TFKB'nin sektöre göre piyasa riskine karşı daha hazır ve sağlam olduğu şeklinde yorumlanabilir. Ancak TFKB'nin notunda özellikle 2016 yılında ciddi bir düşüş olduğu ve 2017'de de negatif tablonun iyileşerek devam ettiği gözlemlenmektedir. Kuveyt Türk, 2015 yılında piyasaya göre daha dayanıksız görünürken, 2016 ve 2017 yıllarında piyasa duyarlılığı notu sektör ortalamasının üzerine çıkmıştır. Albaraka Türk piyasa riskine dayanıklılık noktasında az da olsa piyasa ortalamasının altında kalmış ancak 2017 yılında sektör ortalamasına yakın hale gelmiştir. Yeni kurulan kamu katılım bankalarındaki durum incelendiğinde, Vakıf Katılım'ın aktif olduğu 2015 ve 2016 yıllarında piyasa dayanıklılığ1 konusunda sektör ortalamasının altında kaldığı görülmüştür. Ancak Ziraat Katılımın aktif olduğu üç yılda da sektöre göre piyasa risklerine karşı daha dayanıklı olduğu söylenebilir.

Tablo 4'de Tablo 3 ile hesaplanan kalemlere (Sermaye yapısı, Aktif kalitesi, Yönetim performans1, Karlılık, Likidite ve Piyasa duyarlılığı) ait toplam skorlar ağırlık oranlarıyla çarpılarak her bir kalemin kendi içinde toplamları alınmıştır. Böylece her bir bankanın 20152017 yılları arasındaki toplam bileşik CAMELS notu hesaplanmıştır. Tablo 4, Grafik 7 vasıtasıyla grafik haline getirilerek yorumlanmıştır. 


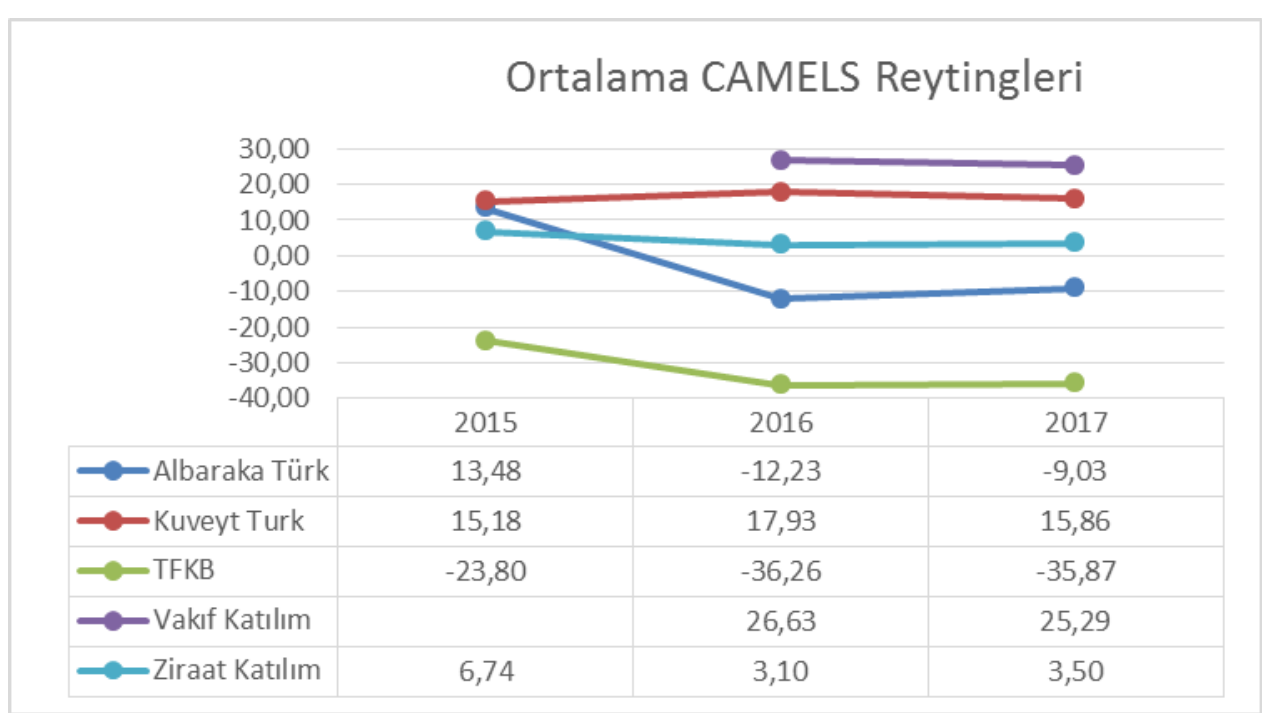

Grafik 7. 2015-2017 Yılları Arası herbir Katılım Bankasına ait Bileşik CAMELS Değerleri

Grafik 7 her bir katılım bankasına ait bileşik CAMELS notlarını görsel olarak göstermektedir. Bileşik ortalama CAMELS reytingleri incelendiğinde en yüksek nota sahip olan bankanın bir kamu katılım bankası olan Vakıf Katılım olduğu görülmektedir. Vakıf Katılım'ın 2016 yılına ait karlılık ve piyasa duyarlılığı kalemleri hariç diğer tüm kalemlerde sektör ortalamasının üzerinde reyting skorlarına sahip olduğu görülmektedir. Böylece bileşik notunda da sektör ortalamasının üzerinde reytinge sahip olmuştur. İkinci sırada olan Kuveyt Türk'ün de bileşik CAMELS notu açısından değerlendirildiğinde her yıl için sektörün ortalama notunun üzerinde bir skora sahip olduğu dolayısıyla sağlamlık açısından iyi durumda olduğu değerlendirilebilir. CAMELS puanı en yüksek 3. banka diğer bir kamu katılım bankası olan Ziraat Katılım'dır. Ziraat Katılımın her bir kalemdeki performansı ayrı ayrı irdelendiğinde aktif kalitesi, yönetim performansı ve piyasa duyarlılığı kalemlerinde her yıl sektör ortalamasının üzerinde puana sahip olduğu görünmektedir. Dolayısıyla bu kalemlerde sektöre göre sağlam bir yapıya sahip olduğu söylenebilir. CAMELS reyting sisteminde 4. Sıraya sahip olan Albaraka Türk 2015 yılında sektör ortalamasının üzerinde bir skora sahipken 2016 ve 2017 yıllarında reyting notunda düşüş olmuş ve ortalamanın altında nota sahip olmuştur. Son sıradaki TFKB'nin ise her yıl ortalamanın altında bir skora sahip olduğu, dolayısıyla CAMELS sistemini oluşturan kalemlerde bankanın yeterli sağlamlığa sahip olmadığı söylenebilir.

\section{SONUÇ}

Çalışmada Türk Bankacılık Sisteminin gelişen yüzü katılım bankacılığı sektörüne yeni giriş yapan kamu katılım bankaları ve devam eden mevcut katılım bankaları, bir performans değerlendirme sistemi olan CAMELS değerlendirme sistemi ile incelenmiştir.

CAMELS sistemini oluşturan kalemlere ait skorlar belirlenen ağırlıklar nispetinde hesaplanmış ve bankaların bu kalemlerde sektöre nazaran ne ölçüde başarı gösterdiği değerlendirilmiştir. Bu değerlendirmeyi yaparken CAMELS sistemini oluşturan 6 ana kalem ve 20 adet rasyo kullanılmıştır. 
Elde edilen sonuçlara göre yeni kurulan katılım bankalarının bu kalemlerde sektöre nazaran daha iyi bir performans sergiledikleri ve CAMELS sistemini oluşturan sermaye yapısı, aktif kalitesi, yönetim performansı, karlılık, likidite, piyasa riski kalemlerinde sektöre göre sağlam bir yapıya sahip olduğu değerlendirilebilir. Her kalem bazında bankalar aşağıdaki gibi değerlendirilebilir:

1) Her iki kamu katılım bankasının da ilk kuruluş yılında sağlam bir sermaye yapısı ile kurulduğunu daha sonra bu durumun zayıflamaya başladığı görülmektedir. Ancak 2017 yılında Ziraat Katılım haricindeki hemen her katılım bankasının sermaye yapısının pozitif ve sağlam olduğu ve sadece Ziraat Katılımın sektör ortalamasının altında kalarak negatif bir nota sahip olduğu görülmektedir.

2) Aktif kalitesi açısından en yüksek nota sahip olan iki bankanın yeni kurulan kamu katılım bankaları olan Ziraat Katılım ve Vakıf Katılıma ait olduğu görülmüştür. Yeni kurulmaları sebebiyle sorunlu kredilerinin az olması bu konuda kamu katılım bankalarının avantajlı olmasını sağlamaktadır.

3) Yönetim performansı kaleminde sektöre göre en yüksek puana sahip olan bankaların sırasıyla Ziraat Katılım ve Vakıf Katılım olduğu görülmüştür. Bu durum kalemi oluşturan rasyolarda kamu katılım bankalarının başarılı olduğunu göstermektedir. Yine Kuveyt Türk de sektörün üzerinde bir ortalamaya sahipken, Albaraka Türk ve TFKB'nin sektörün altında performans notuna sahip olduğu görülmüştür. Bu kalemin hesaplanmasında takipteki krediler ve diğer faaliyet giderlerinin dikkate alındığı düşünülürse bu konuda kamu katılım bankaları ve Kuveyt Türk'ün olumlu bir portre çizdiği, diğer iki bankanın bu konuda nispeten başarısız olduğu söylenebilir.

4) Karlılık kaleminde yeni kamu katılım bankalarının sektörün altında bir performans gösterdiği, bu tablonun 2017 yılında pozitife doğru ilerlediği görülmektedir. Bankaların yeni kurulması sebebiyle kuruluş maliyetlerinin de yüksek olması göz önüne alınarak karlılık kalemlerinin düşük olması beklenebilir. Diğer üç katılım bankasının genel olaral sektör ortalamasının üzerinde bir skora sahip olduğu ancak Albaraka Türk’ün karlılık rasyolarının 2017 itibarıyla sektör ortalamasının altına düştüğü görülmektedir.

5) Likidite kaleminde en yüksek skora Vakıf Katılım bankasının sahip olduğu görünmektedir. Ziraat Katılım ise 2016 yılında likidite rasyoları açısından sektöre göre yüksek bir skora sahip olsa da 2015 ve 2017 yılında sektörün altında likidite rasyolarına sahip olmuştur. Bu durum bankanın likit aktiflerini azaltmasından kaynaklanabilir.

6) Son kalem olan Piyasa duyarlılığı kaleminde, Ziraat Katılım her üç yıld da sektmrün üzerinde bir ortalamaya sahip olmuştur. Vakıf Katılım ise 2017'de seyir daha olumlu olsa da aktif olduğu her iki yılda da sektörün altında bir skora sahip olmuştur. Bu durum, Ziraat Katılım'ın piyasada oluşabilecek risklere karşı daha dayanıklı olduğu şeklinde değerlendirilebilir.

Sonuç olarak, CAMELS sistemini oluşturan herbir kalemin sistem üzerindeki ağırlıkları hesaba katılarak ortalama CAMELS skorları hesaplandığında Ziraat Katılım ve Vakıf Katılım bankalarının her üç yılda da sektör ortalamasının üzerinde skorlara sahip olduğu görülmektedir. En yüksek skor Vakıf Katılım'a aitken, onu sırasıyla Kuveyt Türk ve Ziraat Katılım takip etmektedir. Albaraka Türk'ün 2015 dışındaki yıllarda, TFKB'nin ise tüm yıllarda sektör ortalamasının altında CAMELS reytingine sahip olduğu görülmektedir. Bu durum olası risklerde bu bankaların daha dayanıksız olabileceği şeklinde yorumlanabilir. 
Çalışma ilerleyen yıllarda kapsadığı dönem açısından veya Türk Bankacılık Sistemindeki diğer bankaların da çalışmaya dahil edilmesi suretiyle genişletilebilir.

\section{KAYNAKLAR}

Aspal, P. K.- Dhawan, S. (2016), "Camels Rating Model For Evaluating Financial Performance of Banking Sector: A Theoretical Perspective", International Journal of System Modeling and Simulation, 1(3), 10-15.

Aysan, A. F.- Dolgun, M. H.- Turhan, M. I. (2013), "Assessment of the Participation Banks and Their Role in Financial Inclusion in Turkey", Emerging Markets Finance \& Trade, 49, 99-111.

Biçer, A. (2011), "Participation Banks In Turkey, Is There Still an Ample Room to Go Further?" http://www.tkbb.org.tr/akademik-calismalar, (11.09.2018).

Derviz, A. - Podpiera, J. (2008), "Predicting Bank CAMELS and S\&P Ratings - The Case of the Czech Republic", Emerging Markets Finance and Trade, 44(1), pp.117-130.

Dincer, H.- Gencer, G.- Orhan, N. - Şahinbaş, K. (2011), "A performance Evaluation Of The Turkish Banking Sector After The Global Crisis Via CAMELS Ratios", ProcediaSocial and Behavioral Sciences, 24, pp.1530-1545.

Doğan,N.(2017),"Pazara Dört Yeni Banka M1 Geliyor?", http://www.hurriyet.com.tr/ekonomi/pazara-dort-yeni-banka-mi-geliyor-aralarinda40684685, (29.01.2019)

Ege, İ. - Topaloğlu, E. E.- Karakozak, Ö. (2015), "Camels Performans Değerleme Modeli̇: Türkİye'deki Mevduat Bankaları Üzerine Ampirik Bir Uygulama", Ömer Halisdemir Üniversitesi İktisadi ve İdari Bilimler Fakültesi Dergisi, 8(4), ss.109-126.

Eyceyurt Batır T.- Güngör, B. (2016), "Bank Efficiency in TURKEY: Participation Banks Versus Conventional Banks", International Journal Of Business And Management Studies, ss.9-22.

Eyceyurt Batır, T.- Volkman, D. A. - Gungor, B. (2017), "Determinants of bank efficiency in Turkey: Participation banks versus conventional banks", Borsa Istanbul Review, 17(2), pp.86-96.

Gilbert, R. A.- Meyer, A. P. - Vaughan, M. D. (2000), "The Role of a CAMEL Downgrade Model In Bank Surveillance", Federal Reserve Bank of St. Louis Working Paper Series (2000-021), pp.1-34.

Gümüş, F. B.- Nalbantoğlu, Ö. (2015), "Türk Bankacilik Sektörünün Camels Analizi Yöntemiyle 2002-2013 Yılları Arasında Performans Analizi", Afyon Kocatepe Üniversitesi İktisadi ve İdari Bilimler Fakültesi Dergisi, 17(2), ss.83-106 
Kabir, A. - Dey, S. (2012), "Performance Analysis Through CAMEL Rating: A Comparative Study Of Selected Private Commercial Banks In Bangladesh", Journal of Politics \& Governance, 1(2/3), pp.16-25.

Kartal, M. T. - Demir, C. H. (2017), "An Analysis on Industry Share Target Of Participation Banking In Turkey", Route Educational and Social Science Journal, 4(3),pp.33-58.

Kaya, Y. T. (2001), Türk Bankacılık Sektöründe Camels Analizi, Bankacılık Düzenleme ve Denetleme Kurumu MSPD Çalışma Raporu(2001/6), ss.1-20.

Masood, O.- Ghauri, S. M. K. - Aktan, B. (2016), "Predicting Islamic Banks Performance Through CAMELS Rating Model", Banks and Bank Systems, 11(3), pp.36-43

Nurazi, R. - Evans, M. (2005), "An Indonesian study of The Use of CAMEL (S) Ratios As Predictors Of Bank Failure" Journal of Economic and Social Policy, 10(1), 6.

Roman, A. - Şargu, A. C. (2013), "Analysing the financial soundness of the commercial banks in Romania: An approach based on the camels framework", Procedia Economics and Finance, 6, 703-712.

Rozzani, N.- Rahman, R. A. (2013), "Camels And Performance Evaluation Of Banks In Malaysia: Conventional Versus Islamic", Journal of Islamic Finance and Business Research, 2(1), pp.36-45.

Sakarya, Ş. (2010), "Camels Derecelendirme Sistemine Göre İMKB'deki Yerli ve Yabanc1 Sermayeli Bankalarin Karşılaştırmali Analizi", Akademik Araştırmalar ve Çalışmalar Dergisi (AKAD),ss.7-21.

Utku, M. (2017), "TKBB Başkanı Utku, AA Finans Masası'na konuk oldu/Interviewer: B. Y. Elif Ferhan Yeşilyurt", https://www.aa.com.tr/tr/ekonomi/tkbb-baskani-utku-aafinans-masasina-konuk-oldu/959832, (13.10.2018).

Yüksel, S.- Dincer, H. - Hacıoğlu, U. (2016), "CAMELS-based Determinants for the Credit Rating of Turkish Deposit Banks", International Journal of Finance \& Banking Studies (2147-4486), 4(4), pp.1-17. 
